\title{
Ameliorative effect of salicylic acid in salinity stressed Pisum sativum by improving growth parameters, activating photosynthesis and enhancing antioxidant defense system
}

\author{
Farhan Ahmad ${ }^{1}$, Ananya Singh ${ }^{2}$ and Aisha Kamal ${ }^{1 *}$ \\ ${ }^{1}$ Department of Bioengineering, Integral University, Lucknow, India \\ ${ }^{2}$ Department of Biosciences, Integral University, Lucknow-226026, India
}

\begin{abstract}
Salt stress unfavorably disturbs the physiological processes and morphological organization of plants that limit plant growth and development. Salicylic acid (SA) is an important signal molecule, also acts as growth regulator that alleviates the hostile impact of salinity on plants. Pisum sativum L. (Fabaceae) is a salt-sensitive plant. This study was conducted to to explore the regulating mechanism of exogenous SA on the germination,growth, relative water content, chlorophyll content, ROS concentrations, and antioxidant activities of Pisum sativum sample under 50, 100 and $150 \mathrm{mM} \mathrm{NaCl}$ conditions. Pisum sativum showed reduced growth rate, dry weight, decreased photosynthetic Pigments, alteration in nutritional contents under 50 and $100 \mathrm{mM} \mathrm{NaCl}$ level of salinity. Severity of adverse effect was maximum at $150 \mathrm{mM}$ of $\mathrm{NaCl}$. However, presoaking application of SA efficiently retains the growth parameters, photosynthetic efficiency, and improved antioxidant defense system. However, at higher salinity levels i.e. at $150 \mathrm{mM}$ $\mathrm{NaCl}$ saline condition, there was no noteworthy variance in the mitigation in terms of growth and other physiological responses were observed. We demonstrate that application of SA can meritoriously neutralize the adverse effect of moderate saline conditions on growth and development of Pisum sativum.
\end{abstract}

KEY WORDS: SALICYLIC ACID, SALT STRESS, ROS, ANTIOXIDANTS, PHOTOSYNTHESIS

\section{ARTICLE INFORMATION:}

*Corresponding Author: aisha@iul.ac.in

Received $27^{\text {th }}$ Nov, 2017

Accepted after revision $26^{\text {th }}$ Sep, 2017

BBRC Print ISSN: 0974-6455

Online ISSN: 2321-4007 CODEN: USA BBRCBA

Thomson Reuters ISI ESC and Crossref Indexed Journal

NAAS Journal Score 2017: 4.31 Cosmos IF: 4.006

- A Society of Science and Nature Publication, 2017. All rights reserved.

Online Contents Available at: http//www.bbrc.in/

DOI: $10.21786 / \mathrm{bbrc} / 10.3 / 22$ 


\section{INTRODUCTION}

Being sessile in nature and increased anthropogenic activities in the advanced era, plant exposed to innumerable abiotic stresses, such as heat cold stress, salinity, heavy metals, ultraviolet radiation, nutrient changes (Khan and Khan, 2013). Under natural conditions, salinity has a multiple effect on plant growth by reducing water absorption, creating ion imbalance or turbulence that leads to plant toxicity (Roussos et al., 2007). This negatively affects growth parameter viz germination efficiency, leaf area, length and root and shoot dry weight, protein synthesis, photosynthesis and chlorophyll, lipid breakdown, reactive oxygen species formation (Munns, 2005; Parida and Das, 2005). Over-production of ROS caused and declining photosynthesis (Gunes et.al., 2007; Steduto et al 2000). To readdress the loss due to ROS generation, plants have an effective defense system composed of both, enzymatic (SOD, CAT, POD) and non-enzymatic (Proline, Phenol contents, carotenoids, and tocopherol) and antioxidants systems. However, plants showed different response to salinity according to the plant tolerance capability and developmental stage. The treatment with $150 \mathrm{mM} \mathrm{NaCl}$ level of salinity enhanced about $72 \%$ of POD activity in salt-tolerant cotton (Gossett et al.,1994). Thus, it is important to enhance the salinity resistance of plants and endeavor different compound to reduce plant stress.

SA is a phenolic growth regulator that assumes conspicuous and expanded role in biochemical and physiological reaction to abiotic stress (Hayat et al. 2012).It has been also revealed that exogenously applications of SA can significantly enhanced overall growth of plant under both salinity and non-salinity by adjusting antioxidants scavenging system (Ismail 2013). Furthermore, SA also reduced the destructive effects of several abiotic stresses by regulating proline concentration and other osmolytes production (Pirasteh- Anosheh et al. 2014; Chandrakar et al. $2016 \mathrm{Ma}$ et.al, 2017).

However, confirmation regarding the lessening of salinity stress by exogenous SA is slightly questioned. Arfan et al. (2007) and Li et al. (2014), recounted that spraying SA could balance direct salt stress actuated development restraint, while no change happened at high convergences of salt stress. Therefore, the action of SA to suppress salt stress on concentration and plant species needto be further clarified. Pea (Pisum sativum L.) second important leguminous crop belongs to family Fabaceae, grown throughout the world in winter to early summer, used both in human nutrition and as fodder. The nutritional value of pea plant cannot be neglected as it is an important source of major biomolecules protein, carbohydrate (Hussein et al; 2006), water-soluble fibers, vitamins (vitamin B1), antioxidants (Mukerji 2004) calcium, phosphorus, fibers, minerals and lutein with a small quantity of iron. It also contains isoflavones which reduced the risk of cancer. It can be grown on a different soil texture but unfavorably influenced by different abiotic burdens, for example, soil corrosiveness, aluminum toxicity and salinity stress. Field pea is extremely sensitive to salinity stress. Regrettably, insufficient studies are available on the growth and development of $P$. sativum under salinity stress. Additionally, the defensive role of phytohormones especially role of SA in ameliorating the detrimental effect of salt stress on $P$. sativum to increase its salt tolerance is mystical.

The aim of present study was to elucidate the alleviating effect of SA in $P$. sativum plants under different concentration of salt treatment by studying various morphological, physiological and biochemical parameters such as biomass yield, total protein and sugar, relative water and proline content. The analysis of antioxidant activities were also done to analyzed ROS generation.

\section{MATERIALS AND METHODS}

\section{PLANT MATERIALS AND GROWTH CONDITIONS}

The $P$. sativum L. (var. AP3) seeds were acquired from the local seed distributor. Viable and uninfected seeds were picked and washed at first with $0.1 \%(\mathrm{v} / \mathrm{v})$ sodium hypochlorite solution for 2- 5 min following thorough washing with Double Distilled water (DDW). Sterilized seeds were pre-soaked in different treatments of salinity sand salicylic acid for overnight as follows: T0 (distilled water); T1 (1 mM SA solution); T2 (50 mM NaCl solution); T3 (50 mM NaCl with $1 \mathrm{mM} \mathrm{SA}$ ); T4 (100mM $\mathrm{NaCl}$ solution); T5 (100 mM NaCl with $1 \mathrm{mM} \mathrm{SA})$; T6 (150 mM NaCl solution); and T7 (150 mM NaCl with 1 mM SA). Healthy seeds were then placed for germination in petriplates $(15 \mathrm{~cm})$ having two layers of wet filter paper presoaked with DDW and kept in culture rooms at a light intensity of $100 \mu \mathrm{mol} \mathrm{m} \mathrm{m}^{-2} \mathrm{~s}^{-1}$ and a $14 / 10 \mathrm{~h}$ (day/ night) photoperiod for generation of complete plantlet. Irrigation was done twice in a week for different treatment plants with corresponding solution to keep the field capacity at $70-75 \%$. The experimental condition was maintained through-out the study period. Analyses were carried out after 3 days, when obvious external differences were observed between the plants subjected to different treatments.

\section{ANALYSIS OF GROWTH AND BIOMASS}

After the completion of experiment (30 days), one intact plantlet (roots, shoot, leaf) were indiscriminately selected from each treatments. The plantlet height, fresh and dry weight of roots and stems was obtained by elec- 
tronic scales. Total germination percent was calculated by using equation:

$(\mathrm{TG})=($ total number of germinated seeds/total seed $) \times 100$.

\section{RELATIVE WATER CONTENT}

A $0.5 \mathrm{~g}$ of freshplant sample was weighed (fresh weight, $\mathrm{WF}$ ) in the wake of rehydrating for $24 \mathrm{~h}$ oblivious (soaked saturated weight, WS) and after broiler drying at $85^{\circ} \mathrm{C}$ for $24 \mathrm{~h}$ to a steady weight (WD). The RWC was computed utilizing the equation:

$\mathrm{RWC}(\%)=[(\mathrm{WF}-\mathrm{WD}) /(\mathrm{WS}-\mathrm{WD})]$

\section{TOTAL FREE PROLINE CONTENT}

Proline analysis was done by techniques portrayed by Bates et al (1973) with a few adjustments. The absorbance was measured at $520 \mathrm{~nm}$ utilizing toluene as a blank. The proline concentration was estimated utilizing proline standards $(0-50 \mathrm{mg} / \mathrm{mL})$.

\section{Determinations of photosynthetic pigments (total chlorophyll and total caretenoids)}

The determination of chlorophyll pigments was done by Arnon (1949) method with some modification. Absorbance were taken by uv-visible spectrophotometer at 645 $\mathrm{nm}$ for chlorophyll'a'and $663 \mathrm{~nm}$ for chlorophyll ' $\mathrm{b}$ ' using $80 \%$ acetic acid as a blank. Calculation was done by using the following equations:

Chlorophyll a: 12.7(A663) - 2.69(A645)

Chlorophyll b: 22.9(A645) - 4.68(A663)

The Carotenoid estimation was done by Kirk and Allen, 1965 by using equations

Carotenoids $=\mathrm{A} 480+(0.114 \times \mathrm{A} 663)-(0.638 \times \mathrm{A} 645)$

\section{TOTAL PROTEIN CONTENT}

Total protein content was estimated in each sample through the method of Lowry et al, (1951). The proteins were quantified using the supernatants of samples with BSA as a standard.

\section{Assessments of Antioxidant Activity}

For enzyme extract, $0.3 \mathrm{~g}$ of plant sample was crushed in a chilled mortar with $8 \mathrm{~mL}$ of $50 \mathrm{mM}$ phosphate buffer solution $(\mathrm{pH} 7.8)$ containing $1 \%$ polyethylene pyrrole (PVP) at $4^{\circ} \mathrm{C}$. The homogenate was centrifuged at 10,000 $\mathrm{rpm}$ for $15 \mathrm{~min}$ at $4^{\circ} \mathrm{C}$. Supernatant were used to quantify the activity. SOD activity was evaluated by monitoring its capability to obstruct the photochemical reduction of nitrobluetetrazolium salt (Giannopotitis and Ries, 1977). CAT activity was measured by degrading of $\mathrm{H}_{2} \mathrm{O}_{2}$ (Aebi
(1984). The POD activity was estimated using guaiacol as standard (Klapheck et al., 1990).

\section{DATA ANALYSIS}

Data were tested using analysis of variance (ANOVA) with Graphpad Prism version 5, and graph was plotted on MS tools version (10) Duncan's multiple range tests was used to detect differences between means. The P-value was set at 0.05 and 0.01 for the ANOVA and Duncan's multiple range tests, respectively.

\section{RESULTS AND DISCUSSION}

Salinity treatments significantly decreased plant growth in terms of germination and plant height of Pisumsativum. On comparison with the non-salt-treated $P$. sativum (T0), the salt treatment $50,100,150 \mathrm{mM} \mathrm{NaCl}$ significantly reduced the germination percentage and plant height by $16.09,39.0849 .4 \%$ and $42.85 \%$, 58.92\% $60.71 \%$ respectively (Fig-2A). The SA treatment abridged the decrease in the germination and plant height of the salt-stressed sample. It was observed that salt treatment significantly decreased the germination percentage and plant height in dose dependent manner. Moreover when compared with SA treated plants, significant increase 9.58\% and $26.4 \%$ in germination percentage and 53.3\%, $34.2 \%$ in plant height under $50,100 \mathrm{mM} \mathrm{NaCl}$ treatment were reported. In plant sample treated with salt concentration $150 \mathrm{mM}$ (T6), plant height significantly decreased by $22.3 \%(\mathrm{P}<0.05)$. However, there was no substantial difference in treatment with and without SA under $150 \mathrm{mM} \mathrm{NaCl}(\mathrm{P}<0.05$, Fig-2B)

Salinity also showed pronounced reduction in the dry mass of the shoots and roots. Compared with nonsalt treated $P$. sativum seedlings (T1), the 50, 100,150 $\mathrm{mMNaCl}$ salt treatment reduced the dry weight by $19.04 \%$, $38.09 \%, 61.09 \%$ in shoot and 26.6\%, 40.1\% and 66.6\% in root (Table-1). The SA mitigated the adverse effect of salinity by improving growth of stressed plant.SA treatment significantly increased the dry mass of the shoots, roots, and (shoot+roots) by $15.3 \%, 22.3 \%$ and $37.5 \%$, under $100 \mathrm{mM} \mathrm{NaCl}$ conditions, and 37.5\%, 60\% and $45 \%$ under $150 \mathrm{mM} \mathrm{NaCl}$ conditions $(\mathrm{P}<0.05)$. There were no noticeable changes observed in the dry mass of shoots and dry mass of roots between SA treatedand non-treated plants under $0 \mathrm{mM} \mathrm{NaCl}$ (T0) and (T1) condition i.e. in unstressed samples.

The RWC is an important parameter in estimating the physiological status of plants. When compared to control (T0), the RWC decreased by $27.2 \%$ and $40 \%$ under $100 \mathrm{mM}$ (T4) and $150 \mathrm{mM}$ (T6) saline conditions respectively with a significant level $(\mathrm{P}<0.05)$. SA treated plant showed reduced salinity effect on the RWC reduction in 


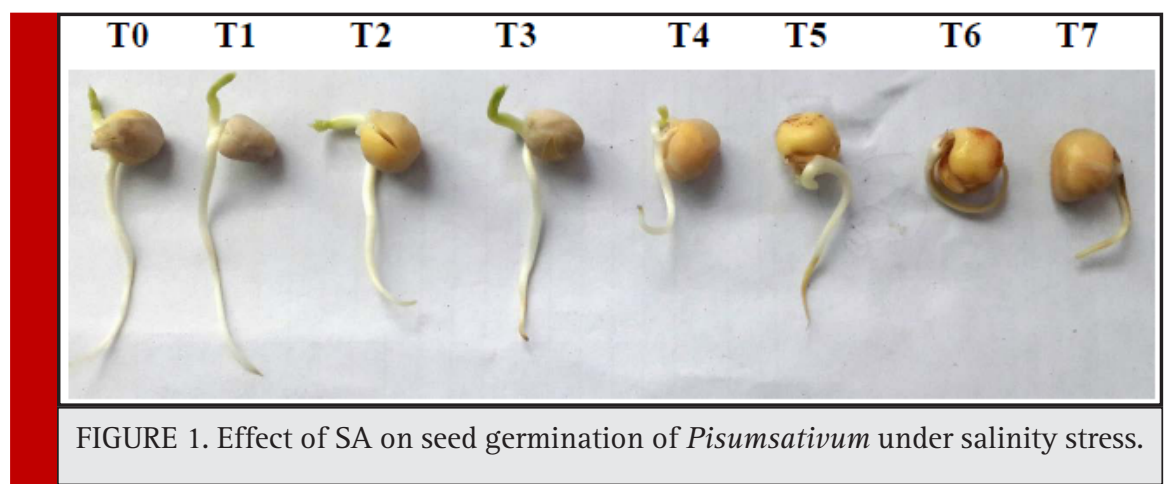

the $0 \mathrm{mM}$ and $50 \mathrm{mM} \mathrm{NaCl}$ saline condition; however, significance level was found $(\mathrm{P}>0.05)$. Under, $100 \mathrm{mM}$ $\mathrm{NaCl}$ level of salinity,a significant improvement in RWC was recorded in plants treated with $\mathrm{SA}(\mathrm{P}<0.05$, Fig3A). Salinity drastically prompted the deposition of free proline content in stressed plants. SA treatment significantly improved the proline content at all salinity levels $(0,50,100$ and $150 \mathrm{mM} \mathrm{NaCl})$ by $4.8 \%, 24.4 \%, 12.7 \%$ and $11.7 \%$ respectively $(\mathrm{P}<0.05$, Fig-3B).

Salt stress causeda decline in the photosynthetic pigments such as chlorophyll a, b, total chlorophyll and carotenoid contents on compared with control. The chl'a' content reduced by $36.3 \%$ under the $50 \mathrm{mM} \mathrm{NaCl}$ salinity level 54.5\% under the $100 \mathrm{mM}$ salt condition, and $72.7 \%$ under the $150 \mathrm{mM}$ saline condition. Whereas SA ameliorated detrimental effect by reducing the decrease in chl'a' content by 18.1\%, 36.3\% and 63.6\% under 50, $100,150 \mathrm{mM} \mathrm{NaCl}$ salinity respectively, when compared to non-SA treated plant $(\mathrm{P}<0.05)$. More drastic reduction in chl'b' were found as salt concentration increased from 50, 100, $150 \mathrm{mM}$ by 23.4\%, 61.7\%, 76.5\% respectively $(\mathrm{P}<0.05)$. Under salt stress conditions, the SA treatment

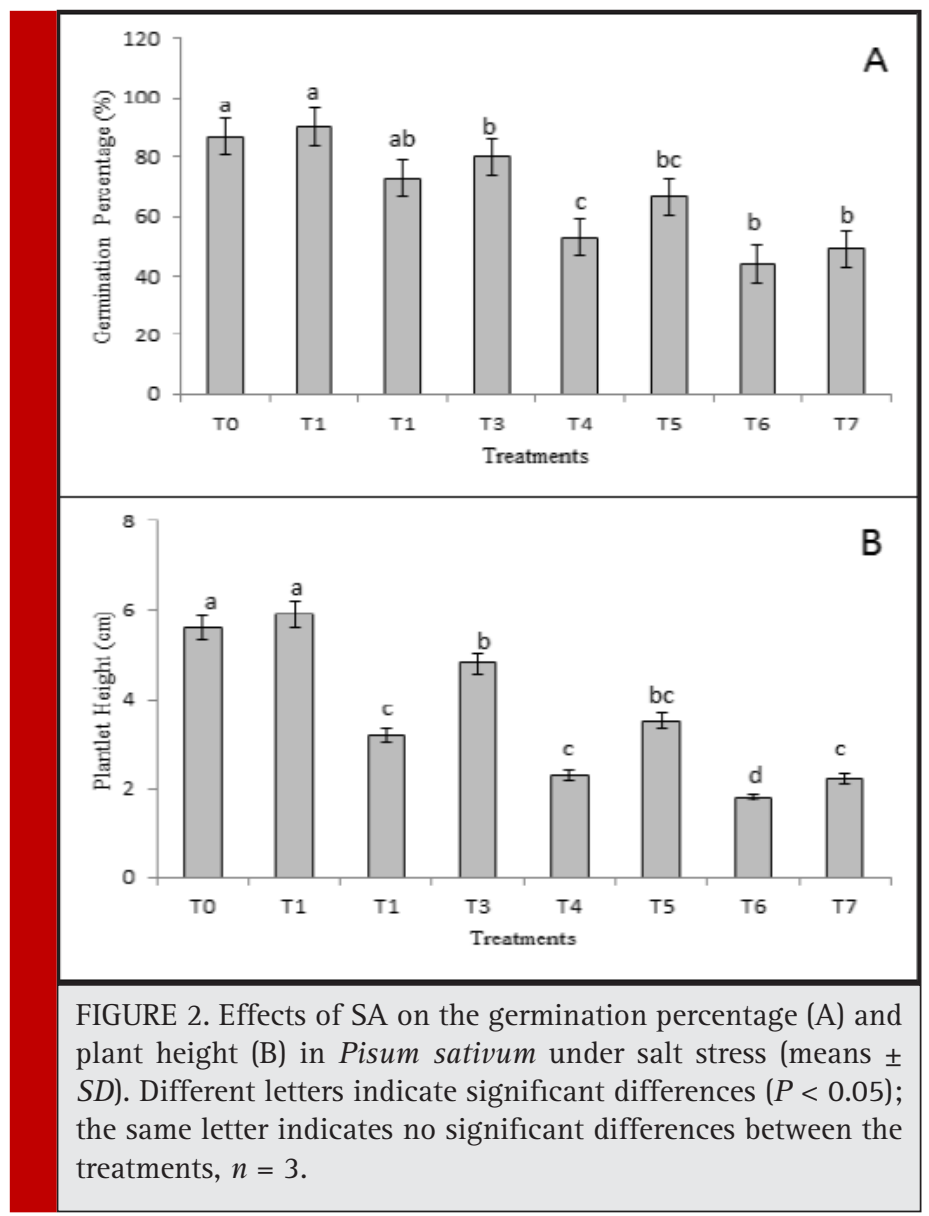


Table 1. Effects of SA on the dry matter of the shoots, roots, and roots + shoots in $P$ sativum grown under salt stress (means $\pm \mathrm{SD}$ ). Different letters indicate significant differences $(\mathrm{P}<0.05)$, the same letter indicates no significant differences between the treatments, $\mathrm{n}=3$.

\begin{tabular}{|l|c|c|c|}
\hline Treatment & Shoot(g) & Root(g) & $\begin{array}{c}\text { Shoot+ } \\
\text { Root(g) }\end{array}$ \\
\hline T0 & $2.1 \pm 1.15^{\mathrm{a}}$ & $1.5 \pm 0.68^{\mathrm{a}}$ & $3.6 \pm 0.49^{\mathrm{a}}$ \\
\hline T1 & $2.3 \pm 0.93^{\mathrm{a}}$ & $1.6 \pm 0.39^{\mathrm{a}}$ & $3.9 \pm 0.98^{\mathrm{a}}$ \\
\hline T2 & $1.7 \pm 1.17^{\mathrm{b}}$ & $1.1 \pm 0.37^{\mathrm{b}}$ & $2.8 \pm 1.52^{\mathrm{bc}}$ \\
\hline T3 & $1.9 \pm 1.3^{\mathrm{ab}}$ & $1.3 \pm .074^{\mathrm{ab}}$ & $3.2 \pm 1.62^{\mathrm{ab}}$ \\
\hline T4 & $1.3 \pm 0.92^{\mathrm{c}}$ & $0.9 \pm 0.56^{\mathrm{c}}$ & $2.2 \pm 1.47^{\mathrm{d}}$ \\
\hline T5 & $1.5 \pm 1.34^{\mathrm{b}}$ & $1.1 \pm 0.45^{\mathrm{b}}$ & $2.6 \pm 1.10^{\mathrm{d}}$ \\
\hline T6 & $0.8 \pm 0.74^{\mathrm{c}}$ & $0.5 \pm 0.61^{\mathrm{c}}$ & $1.3 \pm 0.92^{\mathrm{b}}$ \\
\hline T7 & $1.1 \pm 0.89^{\mathrm{a}}$ & $0.8 \pm 0.56^{\mathrm{b}}$ & $1.9 \pm 0.76^{\mathrm{c}}$ \\
\hline
\end{tabular}

resumed the decrease in the chl'b' content by approximately $12.3 \%$ under the $50 \mathrm{mMNa}$ Clcondition, 49.3\% under $10 \mathrm{mM} \mathrm{NaCl}$, and by $70.3 \%$ under the $150 \mathrm{mM}$ $\mathrm{NaCl}$ condition. Similar responses were also observed in carotenoid and total chlorophyll content. Reduction percentage of carotenoid and total chlorophyll content under $100 \mathrm{mM}$ and $150 \mathrm{mM}$ was recorded by 66.6, 50.1\% and $75.5,72.2 \%$ respectively when compared to control (T0). From the above results, it could be concluded that SA significantly improved the photosynthetic efficiency by improving the pigment contents under different level of salinity (Table-2).

\section{TOTAL PROTEIN AND SUGAR CONTENT}

The protein content in $P$. sativum significantly $(\mathrm{P}<0.05)$ reduced in response to saline stress compared

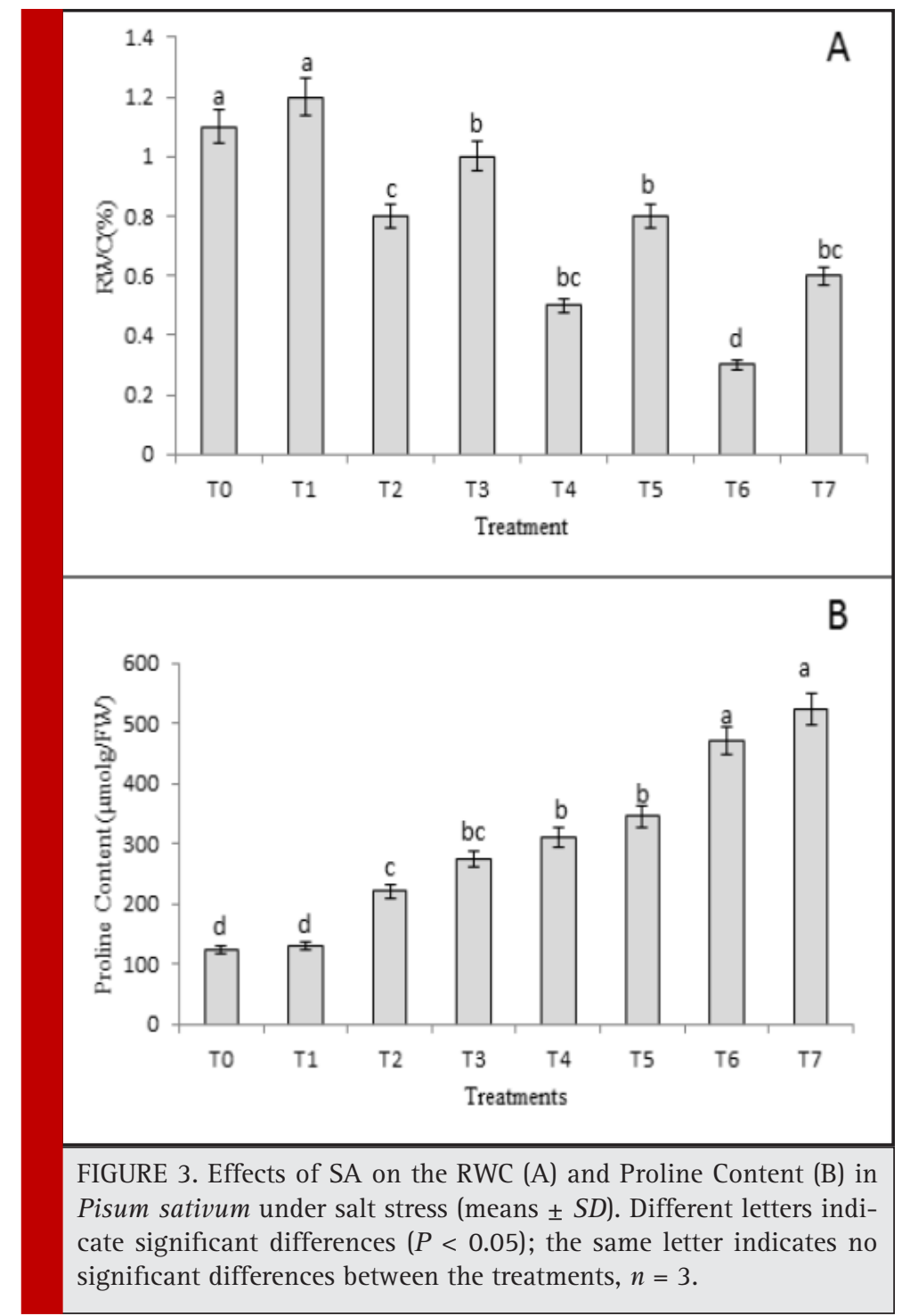




\begin{tabular}{|c|c|c|c|c|}
\hline Treatment & $\begin{array}{c}\text { Chl a Content } \\
(\mathrm{mg} / \mathrm{g})\end{array}$ & $\begin{array}{l}\text { Chl b Content } \\
(\mathrm{mg} / \mathrm{g})\end{array}$ & $\begin{array}{c}\text { Car Content } \\
(\mathrm{mg} / \mathrm{g})\end{array}$ & $\begin{array}{c}\text { Total Content } \\
(\mathrm{mg} / \mathrm{g})\end{array}$ \\
\hline T0 & $1.1 \pm 0.74^{\mathrm{b}}$ & $0.81 \pm 0.41^{\mathrm{a}}$ & $4.2 \pm 0.14^{\mathrm{b}}$ & $1.8 \pm 0.035^{b}$ \\
\hline $\mathrm{T} 1$ & $1.6 \pm 0.62^{\mathrm{a}}$ & $0.85 \pm 0.25^{\mathrm{a}}$ & $5.9 \pm 0.11^{\mathrm{a}}$ & $2.4 \pm 0.014^{\mathrm{a}}$ \\
\hline $\mathrm{T} 2$ & $0.7 \pm 0.32^{\mathrm{c}}$ & $0.62 \pm 0.19^{c}$ & $3.5 \pm 0.05^{\mathrm{c}}$ & $1.2 \pm 0.002^{\mathrm{c}}$ \\
\hline T3 & $0.9 \pm 0.64^{\mathrm{bc}}$ & $0.71 \pm 0.23^{\mathrm{bc}}$ & $3.9 \pm 0.15^{\mathrm{bc}}$ & $1.4 \pm 0.004^{\mathrm{bc}}$ \\
\hline T4 & $0.5 \pm 0.15^{\mathrm{de}}$ & $0.31 \pm 0.09^{d}$ & $1.5 \pm 0.25^{d}$ & $0.9 \pm 0.006^{d}$ \\
\hline T5 & $0.7 \pm 0.23^{\mathrm{d}}$ & $0.41 \pm 0.05^{\mathrm{d}}$ & $2.2 \pm 0.19^{d}$ & $0.7 \pm 0.009^{\mathrm{d}}$ \\
\hline T6 & $0.3 \pm 0.63^{e}$ & $0.19 \pm 0.09^{d}$ & $1.1 \pm 0.48^{\mathrm{d}}$ & $0.5 \pm 0.001^{\mathrm{d}}$ \\
\hline T7 & $0.4 \pm 0.59^{\mathrm{de}}$ & $0.24 \pm 0.08^{\mathrm{d}}$ & $1.4 \pm 0.25^{\mathrm{d}}$ & $0.6 \pm 0.002^{\mathrm{d}}$ \\
\hline
\end{tabular}

to their controls (T1). The content of protein decreased by $29.1 \%$ under $50 \mathrm{Mm} \mathrm{NaCl}, 56.4 \%$ under $100 \mathrm{mM}$ $\mathrm{NaCland} 74.8 \%$ under $150 \mathrm{mM}$ level of salinity. The presoaking treatment of SA significantly improved the protein content by $12.59 \%, 48.1 \%$ and $66.9 \%$ with in 50, 100 and 150mM salinity levels respectively $(\mathrm{P}<0.05$, Table-3). Interestingly, sugar content showed dramatic increase by $58.1 \%, 130.2 \%$ and $312.2 \%$ on increasing salinity level from 50, 100 and $150 \mathrm{mM}$ $\mathrm{NaCl}$. Here also SA significantly improved the sugar

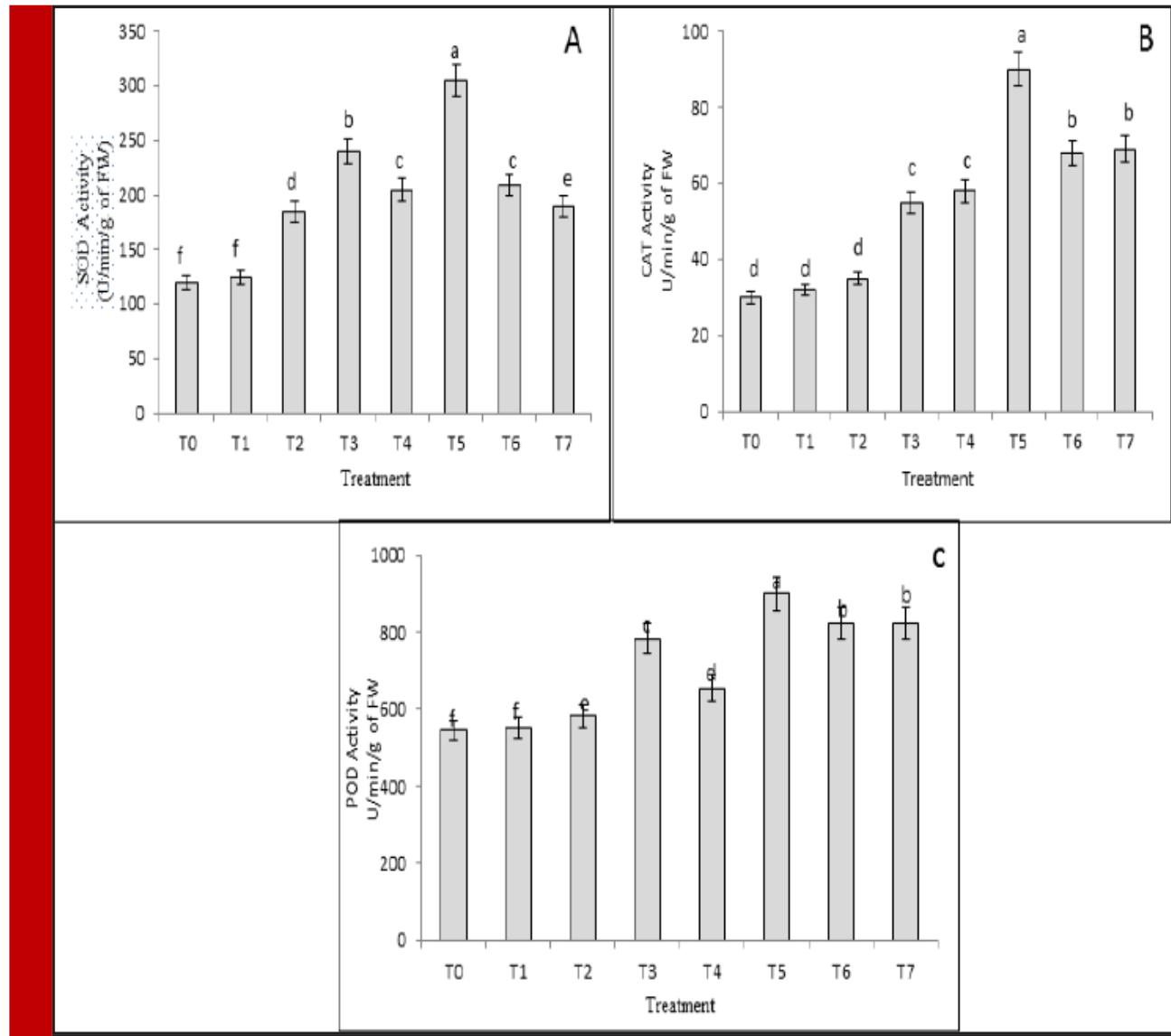

FIGURE 4. Effects of SA on the superoxide dismutase (A), peroxidase (B) and catalase (CAT) (C) in Pisum sativum under salt stress (means $\pm S D$ ). Different letters indicate significant differences $(P<0.05)$; the same letter indicates no significant differences between the treatments, $n=3$. 


\begin{tabular}{|c|c|c|}
\hline Treatment & $\begin{array}{l}\text { Protein Content } \\
\quad\left(\mu \mathrm{g} \mathrm{g} \mathrm{g}^{-1} \mathrm{FW}\right)\end{array}$ & $\begin{array}{l}\text { Sugar Content } \\
\left(\mathrm{mg} \mathrm{g}^{-1} \mathrm{FW}\right)\end{array}$ \\
\hline T0 & $67.56 \pm 1.23^{\mathrm{b}}$ & $39.13 \pm 1.05^{\mathrm{h}}$ \\
\hline $\mathrm{T} 1$ & $70.21 \pm 1.06^{\mathrm{a}}$ & $47.02 \pm 0.45^{g}$ \\
\hline $\mathrm{T} 2$ & $47.80 \pm 0.56^{c}$ & $62.14 \pm 1.41^{\mathrm{f}}$ \\
\hline T3 & $59.01 \pm 0.41^{\mathrm{bc}}$ & $76.08 \pm 0.89^{\mathrm{e}}$ \\
\hline $\mathrm{T} 4$ & $29.40 \pm 0.71^{\mathrm{d}}$ & $90.21 \pm 0.77^{\mathrm{d}}$ \\
\hline T5 & $35.60 \pm 0.87^{\text {cd }}$ & $120.09 \pm 1.23^{\mathrm{c}}$ \\
\hline T6 & $17.43 \pm 1.65^{\mathrm{e}}$ & $161.41 \pm 0.89^{\mathrm{b}}$ \\
\hline T7 & $22.30 \pm 1.67^{\mathrm{f}}$ & $185.25 \pm 0.98^{\mathrm{a}}$ \\
\hline
\end{tabular}

content $(\mathrm{P}<0.05)$. But, no significant differences were observed between treated and non-treated plants in non-saline condition.

\section{Quantification of Antioxidant enzymes SOD, CAT, POD activity}

The antioxidant activities SOD, CAT, POD in the $P$. sativum were pointedly affected by salt and SA treatment (Fig-4). SOD increased by 36.3\% 50.3\% and 48.3\% under the $50,100 \mathrm{mM}$ and $150 \mathrm{mM} \mathrm{NaCl}$ conditions, respectively (Fig-4A). Though, CAT increased by $34.2 \%$ and $63.4 \%$ under the $100 \mathrm{mM}$ and $150 \mathrm{mM} \mathrm{NaCl}$ conditions, respectively, but no significant difference was found between the non-salt condition (T1) and the $50 \mathrm{mM} \mathrm{NaCl}$ condition (T3). Further SA found to mitigate the adverse effect of salinity by significantly enhancing the antioxidant activities. SOD and CAT activity increased by 25.7\%, 42.6\% and 64.4\%, 48.8\% under respective 100 and $150 \mathrm{mM} \mathrm{NaCl}$ salinity when compared to non SA treated plant $(\mathrm{P}<0.05$, Fig-4A and 4B). Similarly POD activity was also increased by $18.4 \%$ under $100 \mathrm{mM} \mathrm{NaCl}$ and $38.1 \%$ under $150 \mathrm{mM}$ $\mathrm{NaCl}$ saline condition (Fig-4C). However, no significant variation were observed in the (SOD, POD, and CAT activity between the SA and non SA treated samples in control conditions (T1) $(\mathrm{P}>0.05)$.

Salt stress confines plant development and morphology by unfavorably affecting different parts of physiology and natural chemistry, for example, photosynthesis, superoxide ion homeostasis, antioxidant enzymes, osmolyte aggregation, and proline metabolism regulation (Misra and Saxena, 2009; Roussos et al., 2013). The present investigation clearly indicated that Pisumsativum is highly salt sensitive plant and presoaking treatment of SA mitigated the deleterious effect of salinity by improving various morphological, physiological and biochemical parameters such as increasing germination percentage, plantlet height, fresh and dry weight, activation of antioxidant activity and also photosynthetic process.

$P$. sativum under low salt stress $(50 \mathrm{mM} \mathrm{NaCl})$ exhibited no ostensible inadaptability due to the saline conditions. Additionally, to a certain degree, the exogenous SA responded the salt stress-prompted growth inhibition of $P$. sativum under $100 \mathrm{mM}$ salinity; however no enhancement occurred under 150mM salinity. In current study, salt stress markedly reduced the drybiomass after treatment with 100 and $150 \mathrm{~mm} \mathrm{NaCl}$ subsequently 30 days of treatment (Table-1). The degree of severity in root was more as associated to shoot because root is the first organ that faces the salinity stress. Besides, expanding indication suggests that SA treatment fundamentally eases the harmful impacts of saltiness on plant development (Shakirova et al., 2003). Iqbal et al. (2006) demonstrated that SA enhanced the inimical impacts of salt stress on the development of wheat cultivars.It has likewise been accounted for that SA-treated maize plants had higher dried mass contrasted untreated plants that were additionally developed under salt stress (Gunes et al., 2007). The variety in assignment of biomass to various organs might be vital to the accomplishment of a seedling to adjusting to another condition (Tang et al., 2015).

In the present investigation, increased RWC and accumulation of free proline in $P$. sativum seedlings following 30 days of salt worry under SA treatment may be a versatile element in enhancing its succulence and keeping up the water adjust because of salinity actuated osmotic stress (Fig. 2A). These results are partially similar to the other study conducted on plant showed that proline accumulation regulate osmotic balance at the cellular level, retain membrane integrity and therefore, combat the injurypersuaded by salt (Misra and Saxena 2009; Ma et.al, 2017),.

The diminishment of leaf chlorophyll under high saltiness has been credited to the pulverization of pigments and the unsteadiness of the pigment protein complex (Jaleel et. al., 2009). The expansion of SA to $\mathrm{NaCl}$-focused on plants particularly enhanced the photosynthetic content, proposing that the upsurge in chlorophyllpigments on treatment withSA may be due to capability of SA to improve the movement of specific proteins, consequently animating chlorophyll biosynthesis or decreasing chlorophyll debasement, prompting expanded overall photosynthesis process in salt stress resistance.

The decrease in chlorophyll because of osmotic stress attributed to the major harm to chloroplast layers, which builds the membrane penetrability or loss of membrane uprightness (Tang et. al 2015). Studies have demonstrated that the serious harm caused by saltiness stretch is in part because of the era of responsive oxygen species (ROS, for example, hydrogen peroxide (Asada, 2006). The upsurge in ROS was slowed down in plants 
when presoaked with SA, proposing that SA possibly protect cells and sub-cellular systems from ROS cytotoxicity. In fact, plants can protect their tissues from the toxic effects of salt-accumulated ROS by using enzymes such as superoxide dismutase (SOD), catalase (CAT) and peroxidase (POD) (Verhagen et al., 2004). SA found to persuade the activities of antioxidant enzymes in the $P$ sativum under the salinity condition (Fig-3). Otherstudy alsostrongly support that the SA enhanced antioxidantsactivity, which protect the plants from oxidative damage (e.g., Hayat et al., 2008). In recent times, studies have showed that SA also helps incontrolling antioxidant enzyme activities to withstand salinity-induced injury (Horvath et al., 2007; Harfouche et al., 2008).

\section{CONCLUSION}

From the results obtained in the present study, it could be concluded that $P$. sativum is a salt-sensitive leguminous crop and severely affected by salt stress that's lead to the accumulation of ROS, debasement of photosynthetic pigments which resulted in reduced photosynthesis, growth inhibition and reduced biomass production.. However, SA curtailed the lethal effect of salt on the growth and adaptation of plant to saline environment, which was accredited to high activity of the antioxidant enzymes. However further extensive research required to elucidate the mitigating mechanism of SA in stressed plants.

\section{ACKNOWLEDGEMENTS}

The authors are grateful to the founder Vice Chancellor Dr. SW. Akhtar, Integral University, for providing all facilities required for study. The authors are also indebted to the Publication Cell, Integral University, Lucknow, for quick and crisp revision of manuscript, needful suggestion and for allotting manuscript number IU/RED/2017MCN000157.

\section{REFERENCES}

Aebi, H. (1984) Catalase in vitro. Methods in enzymology, 105, 121-126.

Anosheh, H. P., Ranjbar, G., Emam, Y., \&t Ashraf, M. (2014). Salicylic-acid-induced recovery ability in salt-stressed Hordeum vulgare plants. Turkish Journal of Botany, 38(1), 112121.

Arfan, M., Athar, H. R., \&t Ashraf, M. (2007). Does exogenous application of salicylic acid through the rooting medium modulate growth and photosynthetic capacity in two differently adapted spring wheat cultivars under salt stress? Journal of Plant Physiology, 164(6), 685-694.

Arnon, D. I. (1949). Copper enzymes in isolated chloroplasts. Polyphenoloxidase in Beta vulgaris. Plant physiology, 24(1), 1.
Asada, K. (2006). Production and scavenging of reactive oxygen species in chloroplasts and their functions. Plant physiology, 141(2), 391-396.

Bates, L. S., Waldren, R. P., \& Teare, I. D. (1973). Rapid determination of free proline for water-stress studies. Plant and soil, 39(1), 205-207.

Chandrakar, V., Naithani, S. C., \&t Keshavkant, S. (2016). Arsenic-induced metabolic disturbances and their mitigation mechanisms in crop plants: A review. Biologia, 71(4), 367-377.

Giannopolitis, C. N., \&t Ries, S. K. (1977). Superoxide dismutases I. Occurrence in higher plants. Plant physiology, 59(2), 309-314.

Gossett, D. R., Millhollon, E. P., \&t Lucas, M. (1994). Antioxidant response to $\mathrm{NaCl}$ stress in salt-tolerant and salt-sensitive cultivars of cotton. Crop Science, 34(3), 706-714.

Gunes, A., Inal, A., Alpaslan, M., Eraslan, F., Bagci, E. G., \& Cicek, N. (2007). Salicylic acid induced changes on some physiological parameters symptomatic for oxidative stress and mineral nutrition in maize (Zea mays L.) grown under salinity. Journal of Plant Physiology, 164(6), 728-736.

Gunes, A., Inal, A., Alpaslan, M., Eraslan, F., Bagci, E. G., Et Cicek, N. (2007). Salicylic acid induced changes on some physiological parameters symptomatic for oxidative stress and mineral nutrition in maize (Zea mays L.) grown under salinity. Journal of Plant Physiology, 164(6), 728-736.

Harfouche, A. L., Rugini, E., Mencarelli, F., Botondi, R., \& Muleo, R. (2008). Salicylic acid induces H 202 production and endochitinase gene expression but not ethylene biosynthesis in Castanea sativa in vitro model system. Journal of plant physiology, 165(7), 734-744.

Hayat, S., Hasan, S. A., Fariduddin, Q., \&t Ahmad, A. (2008). Growth of tomato (Lycopersiconesculentum) in response to salicylic acid under water stress. Journal of Plant Interactions, 3(4), 297-304.

Hayat, S., Maheshwari, P., Wani, A. S., Irfan, M., Alyemeni, M. N., \&t Ahmad, A. (2012). Comparative effect of 28 homobrassinolide and salicylic acid in the amelioration of $\mathrm{NaCl}$ stress in Brassica juncea L. Plant physiology and biochemistry, 53, 61-68.

Horváth, E., Szalai, G., \& Janda, T. (2007). Induction of abiotic stress tolerance by salicylic acid signaling. Journal of Plant Growth Regulation, 26(3), 290-300.

Hussein, M. M., Nadia, E. L., Gereadly, H. M., \&t El-Desuki, M. (2006). Role of putrescine in resistance to salinity of pea plants (Pisumsativum L.). J ApplSci Res, 2, 598-604.

Iqbal, M., Ashraf, M., Jamil, A., \& Ur-Rehman, S. (2006). Does seed priming induce changes in the levels of some endogenous plant hormones in hexaploid wheat plants under salt stress?. Journal of integrative plant Biology, 48(2), 181-189.

Ismail, M. A. (2013). Alleviation of salinity stress in white corn (Zea mays L.) plant by exogenous application of salicylic acid. Am J Life Sci, 1(6), 248-55.

Jaleel, C. A., Sankar, B., Sridharan, R., EtPanneerselvam, R. (2008). Soil salinity alters growth, chlorophyll content, 
and secondary metabolite accumulation in Catharanthusroseus. Turkish Journal of Biology, 32(2), 79-83.

Khan, M. I. R., \&t Khan, N. A. (2013). Salicylic acid and jasmonates: approaches in abiotic stress tolerance. Journal of plant Biochemistry and physiology, 1(4).

Kirk, J. T. O., Et Allen, R. L. (1965). Dependence of chloroplast pigment synthesis on protein synthesis: effect of actidione. Biochemical and Biophysical Research Communications, 21(6), 523-530.

Klapheck, S., Zimmer, I., \&tCosse, H. (1990). Scavenging of hydrogen peroxide in the endosperm of Ricinuscommunis by ascorbate peroxidase. Plant and Cell Physiology, 31(7), 1005-1013.

Li, T., Hu, Y., Du, X., Tang, H., Shen, C., \&t Wu, J. (2014). Salicylic acid alleviates the adverse effects of salt stress in Torreyagrandis $\mathrm{cv}$. Merrillii seedlings by activating photosynthesis and enhancing antioxidant systems. PLoS One, 9(10), e109492.

Lowry, 0. H., Rosebrough, N. J., Farr, A. L., \&t Randall, R. J. (1951). Protein measurement with the Folin phenol reagent. Journal of biological chemistry, 193(1), 265-275.

Ma, X., Zheng, J., Zhang, X., Hu, Q., \&t Qian, R. (2017). Salicylic Acid Alleviates the Adverse Effects of Salt Stress on Dianthus superbus (Caryophyllaceae) by Activating Photosynthesis, Protecting Morphological Structure, and Enhancing the Antioxidant System. Frontiers in plant science, 8.

Misra, N., \&t Saxena, P. (2009). Effect of salicylic acid on proline metabolism in lentil grown under salinity stress. Plant Science, 177(3), 181-189.
Mukerji, K.G., 2004. Fruit and vegetable diseases. Hingham, MA, USA: Kluwer Academic Publishers, p. 145.

Roussos, P. A., Gasparatos, D., Kyriakou, C., Tsichli, K., Tsantili, E., \&t Haidouti, C. (2013). Growth, Nutrient Status, and Biochemical Changes of Sour Orange Plants Subjected to Sodium Chloride Stress. Communications in soil science and plant analysis, 44(1-4), 805-816.

Roussos, P. A., Gasparatos, D., Tsantili, E., \&t Pontikis, C. A. (2007). Mineral nutrition of jojoba explants in vitro under sodium chloride salinity. ScientiaHorticulturae, 114(1), 59-66.

Shakirova, F. M., Sakhabutdinova, A. R., Bezrukova, M. V., Fatkhutdinova, R. A., \&t Fatkhutdinova, D. R. (2003). Changes in the hormonal status of wheat seedlings induced by salicylic acid and salinity. Plant science, 164(3), 317-322.

Steduto, P., Albrizio, R., Giorio, P., \& Sorrentino, G. (2000). Gas-exchange response and stomatal and non-stomatal limitations to carbon assimilation of sunflower under salinity. Environmental and experimental botany, 44(3), 243-255.

Tang, H., Hu, Y. Y., Yu, W. W., Song, L. L., \& Wu, J. S. (2015). Growth, photosynthetic and physiological responses of Torreyagrandis. Trees, 29(4), 1011-1022.

Verhagen, J., Put, M., Zaal, F., \&t van Keulen, H. (2004). Climate change and drought risks for agriculture. In The Impact of Climate Change on Drylands(pp. 49-59). Springer Netherlands. 